\title{
Pengaruh Penggunaan Metode Case Based Instruction (CBI) Terhadap Pemahaman Siswa Kelas X pada Materi Hukum- Hukum Gas di SMA Negeri 1 Tompaso
}

\author{
Astrid M. Singal ${ }^{* a}$, Wilson A. R. Rombanga ${ }^{a}$ Djefri Tani ${ }^{a}$ \\ a Kimia, FMIPA, Universitas Negeri Manado, Tondano, 95618, Indonesia
}

\begin{tabular}{l} 
I N F O A R T I K E L \\
\hline Diterima 12 November 2019 \\
Disetujui 31 Desember 2019 \\
\hline Key word: \\
Case based instruction, \\
Students understanding \\
\\
\hline Kata kunci: \\
Case based instruction, \\
pemahaman siswa.
\end{tabular}

\begin{abstract}
A BSTRACT
This study aims to increase the understanding of students taught using the CBI learning method higher than the understanding of students taught using conventional learning methods. This research was conducted at SMA Negeri 1 Tompaso, the sample of this study was class X MIA 2 as an experimental class and X MIA 1 as a control class. It can be seen from the results of the F (One Way ANOVA) test that shows that $F_{\text {count }}>F_{\text {table }}$ is $11.07599>4.04$ and the probability value P value $<0.05$ is $0.001685<0.05$ and the results of the $t$ test are obtained tcount $=3.32812$ table $=1.677$. So, $T_{\text {count }}>T_{\text {table, }}$ then reject $H_{0}$ and accept $H_{1}$ so $\mu_{1}>\mu_{2}$. Based on the analysis of research data it can be concluded that the understanding of students taught by using Case Based Instruction learning methods is higher than the understanding of students taught using conventional learning methods
\end{abstract}

\section{A BSTRAK}

Penelitian ini bertujuan meningkatkan pemahaman siswa yang diajarkan menggunakan metode pembelajaran CBI lebih tinggi dari pemahaman siswa yang diajarkan menggunakan metode pembelajaran konvensional. Penelitian ini dilaksanakan di SMA Negeri 1 Tompaso, sampel penelitian ini adalah kelas X MIA 2 sebagai kelas eksperimen dan X MIA 1 sebagai kelas kontrol. Dapat dilihat dari hasil uji F (One Way ANOVA) menunjukkan bahwa

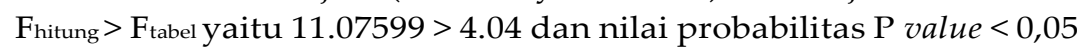
yaitu $0.001685<0,05$ dan hasil uji $t$ diperoleh hasil $t_{\text {hitung }}=3,32812$ $t_{\text {tabel }}=1,677$. Jadi, Thitung $>\mathrm{T}_{\text {tabel }}$, maka tolak $\mathrm{H}_{\mathrm{o}}$ dan terima $\mathrm{H}_{1}$ sehingga $\mu_{1}>\mu_{2}$. Berdasarkan analisis data hasil penelitian dapat disimpulkan bahwa pemahaman siswa yang diajarkan dengan menggunakan metode pembelajaran Case Based Instruction lebih tinggi dari pada pemahaman siswa yang diajarkan menggunakan metode pembelajaran konvensional. *e-mail:astridsingal@gmail.com *Telp: oleh siswa, pernyataan ini menunjukkan bahwa pengetahuan sebelumnya yang ada pada siswa merupakan hal yang sangat penting [1].

Pada penelitian pembelajaran sains menyatakan bahwa siswa yang datang pada pembelajaran sudah mempunyai konsep sendiri tentang materi pembelajaran tersebut, yang sering kali sangat berbeda dengan materi yang diajarkan. Hal ini yang disebut konsep alternatif. Konsep alternatif menghalangi siswa 
belajar selanjutnya karena mereka menafsirkan pengetahuan baru dari konsep alternatif mereka sendiri. Pembelajaran yang mempertimbangkan pengetahuan awal siswa dan memungkinkan siswa mengubah konsep mereka tentang gagasan ilmiah agar bermanfaat untuk memperbaiki konsep alternatif siswa. Case based instruction (CBI) mempunyai tujuan untuk menanamkan pembelajaran di lingkungan sehari-hari dimana siswa terlibat secara aktif membentuk pengetahuan.

Case Based Instruction (CBI) merupakan metode pembelajaran yang melibatkan siswa secara aktif dengan mengunakan kasus-kasus yang terjadi dalam kehidupan sehari-hari yang kemudian dibawah ke dalam kelas untuk meningkatkan pemahaman siswa mengenai pembelajaran. Case Based Instruction (CBI) selalu mengambil contoh dalam kehidupan seharihari dan pengalaman belajar yang mendorong pembelajaran konstruktivisme, tujuan pembelajaran ini mengajarkan topik melalui kasus. Kasus terdiri dari dua bagian utama : pertama adalah situasi kasus untuk pembelajaran dan yang kedua pertanyaan yang terkait kasus dalam pembelajaran. Guru dan siswa mempelajari kasus yang terkait dengan kehidupan sehari-hari secara kooperatif Meskipun penelitian mengenai Case based Instruction (CBI) dalam pendidikan Ilmu Pengetahuan Alam terbatas, namun beberapa penelitian menunjukkan bahwa Case Based Instruction (CBI) efektif dalam menerapkan keterampilan berpikir kritis siswa dan meningkatkan minat belajar mereka dalam mempelajari Ilmu Pengetahuan Alam.

\section{Metode}

Penelitian ini menggunakan desian nonequivalent control group design. Adapun desain pola eksperimen adalah sebagai berikut :

Table 1. Desain penelitian

\begin{tabular}{cccc}
\hline Kelompok & Pretest & Treatment & Posttest \\
\hline Eksperimen & $\mathrm{O}_{1}$ & $\mathrm{X}_{1}$ & $\mathrm{O}_{2}$ \\
Kontrol & $\mathrm{O}_{3}$ & $\mathrm{X}_{2}$ & $\mathrm{O}_{4}$ \\
\hline
\end{tabular}

\section{Hasil dan Pembahasan}

Data hasil penelitian diambil menggunakan soal tes pemahaman siswa.
Untuk soal tes tersebut telah diuji validitas dan reliabilitas sebelum digunakan, dalam pengujian validitas dan reliabilitas melibatkan responden sebanyak 25 siswa di kelas XI MIA 2, sedangkan pada pengujian prasyarat analisis data melibatkan responden sebanyak 25 siswa di kelas X MIA1 sebagai kelas kontrol dan 25 siswa di kelas $X$ MIA 2 sebagai kelas eksperimen di SMA Negeri 1 Tompaso.

\section{Analisis Uji Instrumen Tes Uji Validitas}

Uji validitas item soal dihitung dengan menggunakan korelasi product moment dengan bantuan program MS Excel, dengan taraf signifikansi 0,05 dan $\mathrm{N}=25$ didapatkan rabel $=$ 0,396. Hasil dari perhitungan koefisien korelasi product moment (rhitung) kemudian dibandingkan dengan rtabel, jika nilai rhitung tiap item soal kurang dari rtabel dinyatakan tidak valid dan jika rhitung tiap item soal lebih dari rabel dinyatakan valid. Berdasarkan hasil validasi instrument dari 25 nomor, terdapat 20 nomor valid dan 5 nomor tidak valid.

\section{Uji Reliabilitas}

Hasil analisis reliabilitas menggunakan rumus KR 20 [2]. Rata-rata hasil reliabilitasdari setiap butir soal adalah 0,8866 termasuk kriteria sangat tinggi. Instrumen yang digunakan reliable.

\section{Analisis Data Penelitian}

Perhitungan dalam pengujian hipotesis dilakukan uji F (One Way ANOVA) menggunakan aplikasi Microsoft Excell dan uji T.

Pada hasil pengujian hipotesis didapat Fhitung $=11.07599$ dan dengan menggunakan taraf signifikan 0,05 (5\%), df $1=1, \mathrm{df}_{2}=48$ didapat $F_{\text {tabel }}=4,04$ dan diperoleh nilai sig 0.001685 . Maka Fhitung $>$ Ftabel yaitu 11.07599 $>4,04$ dan nilai probabilitas $\mathrm{P}$ value $<0,05$ yaitu $0.001685<0,05$ dan kemudian dilakukan dengan uji $t$, dengan hasil perhitungan thitung $=3,32812$ dengan $\mathrm{db}=$ n_1 + n_2 $-2=25+25-2=48$ dan $\alpha=0,05$ diperoleh tabel $=t_{(0,05 ; 8)}=1$,677. sehingga $\mathrm{H}_{0}$ ditolak dan $\mathrm{H}_{1}$ diterima. Dapat disimpulkan bahwa pemahaman siswa kelas eksperimen lebih tinggi dari pada kelas kontrol karena pengaruh penggunaan metode CBI pada materi 
hukum-hukum gas kelas X SMA Negeri 1 Tompaso.

Pembahasan

Populasi dari penelitian ini yaitu seluruh kelas X di SMA Negeri 1 Tompaso. Sampel yang digunakan dalam penelitian ini sebanyak 50 siswa, 25 siswa pada kelas kontrol dan 25 siswa pada kelas eksperimen. Desain yang digunakan dalam penelitian ini adalah non-equivalent control group design, dimana kelas kontrol dan kelas eksperimen diambil secara acak kemudian pada kelas eksperimen diberikan treatment tetapi pada kelas kontrol tidak, setelah itu masing-masing kelas diberikan tes pemahaman untuk dilihat nilainya. Tujuan dari penelitian yang dilakukan adalah untuk mengetahui perbedaan signifikan rata-rata pemahaman siswa kelas eksperimen dan kelas kontrol karena pengaruh CBI pada materi hukum-hukum gas di kelas X SMA Negeri 1 Tompaso. Berdasarkan hasil uji prasyarat analisis data, didapatkan kesimpulan untuk uji normalitas adalah Lhitung $=0.110000306 \leq$ Ltabel $=$ 0,173 sehingga data berdistribusi normal, sedangkan untuk uji homogenitas adalah nilai $F_{\text {Hitung }}=1.136642191 \leq \mathrm{F}_{\text {tabel }}=1,98$ maka data berdistribusi homogen sehingga dapat dilakukan uji hipotesis dengan menggunakan uji F (One Way ANOVA) dan uji T.

Hasil diperoleh melalui nilai pretest dan posttest. Nilai pretest diperoleh dari hasil tes yang diberikan diawal pembelajaran ketika kedua kelas sampel belum diberi perlakuan. Nilai posttest diperoleh dari hasil tes yang diberikan diakhir pembelajaran hukum-hukum gas ketika kedua sampel sudah diberi perlakuan. Hasil pada masing-masing kelas sampel dapat dilihat dari selisih antara rata-rata pretest dan rata-rata posttest siswa. Hal ini dapat dilihat pada selisih nilai rata-rata pretest dan posttest yang diberikan pada kedua kelas yaitu nilai rata-rata pretest dan posttest untuk kelas kontrol adalah 52.72 sedangkan untuk kelas eksperimen nilai rata-rata pretest dan posttest adalah 60.28. Hal ini memperlihatkan bahwa nilai rata-rata pretest dan posstest kelas eksperimen lebih tinggi dari nilai rata-rata pretest dan posttest kelas kontrol.

Sesuai dengan pengujian hipotesis dilakukan dengan menggunakan uji $F$ $($ ANNOVA $)$ diperoleh Fhitung $=11.07599 \mathrm{~F}_{\text {tabel }}=$
4,01 maka dari itu sesuai dengan kriteria pengujian jika Fhitung lebih besar dari $\mathrm{F}_{\text {tabel }}$ (thitung $>$ tabel) dan dengan menggunakan uji $\mathrm{T}$ diperoleh thitung $=3,32812$ tabel $=1,677$. Jadi, Thitung $>$ Ttabel, maka tolak Ho dan terima H1 sehingga $\mu_{1}>\mu_{2}$. Maka disimpulkan bahwa terdapat pengaruh antara pemahaman siswa yang menggunakan metode pembelajaran Case-based Intruction dengan pemahaman siswa yang tidak menggunakan metode pembelajaran Case-based Intruction, sehingga masalah yang ingin dipecahkan melalui penelitian ini, terjawab sudah bahwa terdapat pengaruh metode Case Based Instruction (CBI) terhadap pemahaman siswa pada materi Hukum-hukum gas. Dengan demikian metode pembelajaran CBI memberikan pengaruh yang lebih baik terhadap pemahaman siswa pada materi hukum-hukum gas siswa kelas X SMA Negeri 1 Tompaso.

Hasil penelitian ini sejalan dengan salah satu studi yang dilakukan oleh [3] (Eylem Yalcinkaya dan Yezdan Boz, 2017) Case Based Instruction (CBI) efektif dalam meningkatkan pemahaman siswa, kemampuan berpikir kritis dan meningkatkan minat belajar ilmu pengetahuan.

\section{Kesimpulan}

Berdasarkan hasil penelitian, dapat disimpulkan bahwa terdapat pengaruh pemahaman siswa karena metode CBI pada materi hukum-hukum gas.

\section{Daftar Pustaka}

1. Driscoll, M.P. Psychology Of Learning For Instruction. Allyn and Bacon: Toronto, 2005.

2. Sugiyono. Statistika Untuk Penelitian. Alfabeta: Bandung, Indonesia, 2013; ISBN.

3. Yalcinkaya, E.; Yezdan, B. The Effect of CaseBased Instruction On $10^{\text {th }}$ Grade Students' Understanding of Gas Concepts. Journal of Royal Society Chemistry. 2014, Vol 16, 104-120. 